\title{
A MUNKAHELYI EGÉSZSÉGPROGRAMOK MINT KOCKÁZATKEZELÉSI ESZKÖZÖK
}

Szabó Ágnes - Juhász Péter

A munkavállalók egészségi állapotával összefüggő kockázatok komoly károkat okoznak világszerte. A müködési kockázatok ezen változatának kezelésére nyújtanak eszközt a vállalati egészségprogramok, amelyek kiépítésének folyamata és a működtetése nagyon sok párhuzamot mutat a vállalati kockázatkezelési programokkal. Bár az ilyen jólléti programok a nemzetközi gyakorlatban - különösen a multinacionális cégeknél - nagyon népszerüek, itthon egyelőre gyermekcipőben járnak. A területen élenjáró 14 hazai céggel készült interjúk alapján az alkalmazásban itthon különösen az eredmények mérésének terén van szükség fejlődésre.

JEL-kódok: G32, I18, J32, M12, M14, M54

Kulcsszavak: müködési kockázat, vállalati egészségprogram, kockázatkezelés, Legfittebb Munkahely

\section{BEVEZETÉS}

Mitől egészséges egy vállalat? Egy cég egészséges lehet, ha versenyképes: hatékonyan müködik és a lehetőségeinek megfelelően, például az ágazattal együtt növekszik. Nevezhetjük egészségesnek a szervezetet akkor is, ha az alkalmazottai számára egészséges munkakörnyezetet kínál, és törődik a munkavállalói testilelki egészségével, jóllétével. Egy harmadik dimenzióban lehet egészséges egy társaság, ha fogyasztói számára megfelelő, egészséges termékeket és szolgáltatásokat kínál, és a közösség szintjén, ha nemcsak az üzleti szempontokat, hanem a természeti környezetet és más külső érintetteket is szem előtt tartva müködik (Aidoo et al., 2015). Ebben a cikkben a munkavállalók egészségére koncentrálunk.

A téma korántsem napjainkban merült fel elöször: a WHO már 1950-től foglalkozik a munkahelyi egészség témájával (Health Management, 2018). A szervezet rámutatott arra, hogy nemcsak a munka és a munkahely befolyásolja a dolgozók fizikai és mentális egészségi állapotát, hanem a munkavállalók egészségi állapota is hat a vállalatra és annak üzleti teljesítményére. Tehát a munkavállalók egészségmegőrzése több szempontból is fontos, kritikus tényező. Lényeges az egyén és családja szintjén, az egészség helyreállításának költségeit sokszor (részben) viselő társadalom számára, és természetesen a cég jövedelmezőségében érdekelt tulajdonosoknak is. 
Munkával kapcsolatos egészségi okok miatt az Európai Unióban évente 600 millió munkanap vész el. A legtöbb gondot a balesetek, a váz- és izomrendszeri megbetegedések, valamint a munkahelyi stressz okozza. Az EU-OSHA (2018) becslései szerint a munkával összefüggő betegségek évente mintegy 200 ezer halálesetet okoznak Európában. Az EU-ban a munkahelyi egészségkárosodások és sérülések miatti költségek évente 476 milliárd eurót tesznek ki, ami azt jelenti, hogy folyó áron a 2016-os teljes uniós GDP több mint 3,2 százaléka (Eurostat, 2018), a magyar GDP-nek pedig több mint négyszerese ( $\mathrm{KSH}, 2 \mathrm{O}$ - a) veszett el emiatt.

A KSH (2018b) adatai szerint itthon az elmúlt években kedvezőtlen trend indult meg: az egy alkalmazottra jutó betegség miatti távollét 2011-től 2016-ra több mint 25 százalékkal emelkedett, és a fizetett betegszabadság átlagos hossza is majd 20 százalékkal nyúlt meg (1. táblázat). Minél nagyobb létszámú egy vállalkozás, annál több a betegség miatt kieső napok átlagos száma. Míg az 5-49 fös szervezeteknél dolgozók átlagosan fejenként csak 3,8 napot voltak táppénzen vagy betegszabadságon (a fizikaiak 4,6, a szellemiek 2,6 napot), addig az 50-249 közöttieknél ez már 8,7 nap (10,4, illetve 5,7 nap), de ez is jóval alacsonyabb volt, mint a legalább 250 föt foglalkoztató vállalkozásokra jellemző 11,2 nap (14, illetve 7,1 nap) (Vöö, 2018).

\section{1. táblázat}

Betegszabadság a legalább 50 fős vállalkozásoknál

\begin{tabular}{lccccccc}
\hline & $\mathbf{1 9 9 2}$ & $\mathbf{1 9 9 5}$ & $\mathbf{1 9 9 9}$ & $\mathbf{2 0 0 2}$ & $\mathbf{2 0 0 5}$ & $\mathbf{2 0 1 1}$ & $\mathbf{2 0 1 6}$ \\
\hline $\begin{array}{l}\text { Betegség miatti } \\
\text { egész napos távollét }\end{array}$ & 16,9 & 16,5 & 16,2 & 14,0 & 13,1 & 8,1 & 10,3 \\
$\begin{array}{l}\text { Ebből betegszabadság } \\
4,9\end{array}$ & 5,5 & 6,2 & 5,1 & 5,1 & 3,8 & 4,5 \\
\hline
\end{tabular}

Megjegyzés: ${ }^{\star} 1992$-ben legalább 51 fős cégek

Forrás: KSH (2018b)

Az Európai Unió Bizottsága a munkahelyi egészségvédelemre és biztonságra irányuló jogszabályok és politikák modernizálása érdekében 2017-ben kiadott egy közleményt (European Commission, 2017), amely szerint a munkahelyi egészségvédelem és biztonság területére irányuló befektetések kifizetődőek, ugyanis javítják az üzleti termelékenységet és teljesítményt, továbbá makrogazdasági szinten hozzájárulnak a nemzetek versenyképességének a növeléséhez. A munkáltató ilyen irányú befektetése tehát megtérül.

A WHP (Workplace Health Promotion, azaz a munkahelyi egészségfejlesztés) magában foglalja az egészséges életmód népszerüsítését, a munkavállalók 
egészségének és munkaképességének fenntartását és előmozdítását, a munkakörnyezet és a munkamódszerek javítását. Manapság a vállalatoknál - sokszor jogszabályi elöírásokhoz igazodva - rendszeresen szerveznek rutin orvosi szűrést, aminek az is az egyik célja lenne, hogy a cégek az egészségügyi kockázatokat felmérjék, beazonosítsák (Aidoo et al., 2015). A munkahelyi egészség- vagy wellnessprogramoknál nem másról van tehát szó, mint a vállalati kockázatkezelés egyik speciális eszközéröl, amely föként a dolgozókkal kapcsolatos működési kockázatokra koncentrál.

A magyar szabályozás a munkavállalók biztonságának és egészségvédelmének javítását ösztönző intézkedések bevezetéséről szóló o89/391/EGK-irányelvet vette alapul, amely bevezette a kockázat fogalmát. A kockázat ebben az értelmezésben aszimmetrikus: a sérülés vagy az egészségkárosodás veszélyhelyzeti valószínüségének és súlyosságának az együttes hatását jelenti. „A kockázatértékelés gyakorlatilag annak gondos áttekintése, hogy az adott munkahelyen mi károsíthatja vagy veszélyeztetheti a munkavállalókat, és milyen óvintézkedések szükségesek" (Dabrónaki, 2017).

A munkavállalókat számos kockázati tényező érintheti, például a közlekedés, az időjárás - de akár levegő-, zaj-, fény- vagy vegyi szennyeződés is. Jelen cikkben a közvetlen érintettek által nem befolyásolható tényezőkkel nem foglalkozunk részletesen, hanem elsősorban a munkavállalók által befolyásolható kockázati tényezőkre (táplálkozás, mozgás, stressz) és azok kezelésére koncentrálunk. Ugyanakkor nagyon fontos, hogy vállalati szinten minden befolyásoló tényezőt figyelembe vegyünk, és az egészségprogramok minden belső, azaz a szervezet által befolyásolható egészségi kockázati tényező megváltoztatását fontolóra vegyék. Ez utóbbi rendszerint jóval tágabb kört fed le, mint a munkavállalók által befolyásolható kockázati tényezők köre.

\section{A LEGFONTOSABB KOCKÁZATI TÉNYEZÖK}

A munkavállalók jóllétére számos tényező hat. Az egészségkutatások ugyanakkor elsősorban a negatívan ható tényezőkre koncentrálnak, míg az emberi erőforrásmenedzsment, illetve vezetésszervezési és leadership-szakirodalom - talán egyedül a stresszt kivéve - föként a lelki egészségre ható pozitív tényezőkre koncentrál. $\mathrm{Az}$ egészségkockázatok mérlegelésénél is ügyelnünk kell arra, hogy - ahogy a kockázatkezelésnél általában - célszerü a kockázatok csoportosításánál vagy (1) a kiváltó ok, vagy (2) a megjelenési forma (eredmény), vagy (3) a kitettség indoka szerint kategorizálni a faktorokat. Ha a szempontokat keverjük, átfedő kategóriákat kaphatunk, amelyek nemcsak a mérési eredményeket torzítják, de 
rendkívül megnehezítik a kockázatkezelési feladatok felosztását, a felelősségi körök kialakítását is.

A Willis Towers Watson (2016) 34 országban 1669 munkaadót vizsgált, és arra jutott, hogy globálisan és Európát tekintve is a stressz a munkavállalók körében a legfontosabb kockázati tényező, ezt a fizikai inaktivitás követi (2. táblázat). Érdemes ugyanakkor megjegyezni, hogy a táblában megjelenő presenteeism (nem teljes értékű munkahelyi jelenlét) inkább eredményszemléletű kockázati faktor, míg a többi felsorolt tényező inkább kockázatkiváltó ok. Így az átfedő kategóriák miatt az eredmények nehezen értelmezhetők.

2. táblázat

A legjelentősebb munkahelyi egészségkockázati tényezők

\begin{tabular}{cc}
\hline Globálisan & Európában \\
\hline Stressz 64\% & Stressz 74\% \\
Fizikai inaktivitás 53\% & Fizikai inaktivitás $45 \%$ \\
Túlsúly/Elhízás $45 \%$ & Presenteeism 33\% \\
Helytelen táplálkozás 31\% & Túlsúly/Elhízás 32\% \\
Kevés alvás 30\% & Helytelen táplálkozás 31\% \\
\hline
\end{tabular}

Forrás: Willis Towers Watson (2016)

Serxner et al. (2001) 34451 egyesült államokbeli munkavállaló részvételével végzett kutatásában kimutatta: a mentális problémákkal küzdők 150 százalékkal, a hátfájósok 140 százalékkal, a munkahelyi stresszt átélők 131 százalékkal, a fizikailag inaktívak 118 százalékkal, a túlsúlyosak 116 százalékkal vannak többet táppénzen, mint az átlag. A Gallup Intézet kutatásai szerint (Witters-Agrawal, 2015) azon elégedett munkavállalók, akiknek a jólléti pontszámai is magasak, 30 százalékkal kisebb valószínűséggel hiányoznak betegség miatt az elkövetkezendő egy hónapban azokhoz képest, akik bár elkötelezettek, de a jóllétük értékei alacsonyak. Ráadásul éves szinten a magas jólléti pontszámúak 70 százalékkal kevesebb időt töltenek táppénzen.

Az Európai Munkahelyi Biztonsági és Egészségvédelmi Ügynökség felmérése szerint az Európai Unió 27 tagállamában a túlzott munkahelyi stressz az aktív munkavállalók közel egynegyedének egészségét veszélyezteti (Szabó, 2018). A European Survey of Enterprises on New and Emerging Risks 2010-es felmérése (European Agency for Safety and Health at Work, 2010) szerint az európai menedzserek 79 százalékát érinti a munkahelyi stressz, ugyanakkor a vállalatok kevesebb mint 30 százaléka foglalkozik ezzel a problémával. 
A stresszt mint a pszichoszociális kockázat egyik fajtáját 2008 óta a magyar munkavédelmi törvény is definiálja. „Eszerint pszichoszociális kockázat a munkavállalót a munkahelyén érő azon hatások (konfliktusok, munkaszervezés, munkarend, foglalkoztatási jogviszony bizonytalansága) összessége, amelyek befolyásolják az e hatásokra adott válaszreakcióit, illetőleg ezzel összefüggésben stressz, munkabaleset, lelki eredetű szervi (pszichoszomatikus) megbetegedés következhet be” (Dabrónaki, 2017).

A magyar munkavállalók 13 százaléka folyamatosan, további 30 százalékuk gyakran stresszes a munkája miatt (Szinapszis, 2013). A 2013-as Országos Munkahelyi Stressz Felmérés eredményei szerint a gyors munkatempó a legnagyobb stresszfaktor. Ami egyértelmüen csökkenti a munkahelyi stresszt, az a munkakör egyértelműsége, a munka értelmessége és a jó munkahelyi közösség.

Egy uniós felmérés (Eurofound, 2010; Szabó, 2018) szerint a keresőképtelen napok 50-60 százaléka a munkahelyi stresszel magyarázható. Az Európai Munkahelyi Biztonsági és Egészségvédelmi Ügynökség felmérése szerint az unióban évente 136 milliárd euró (a GDP 1 százaléka), ebből Magyarországon 440 milliárd forint vész el a nem kezelt munkahelyi stressz okozta termeléskiesés miatt.

A másik gyakran idézett jelenség a presenteeism (magyarul jelenlétszindrómának szokták fordítani), amely nem teljes értékü munkahelyi jelenlétet jelent. Ilyenkor a munkavállalók mentálisan vagy fizikailag kimerült állapotban, betegen végzik a munkájukat, következésképpen a termelékenységük sem olyan, mintha egészségesek lennének. Ilyenkor ugyanis ugyanahhoz a feladathoz több idő kell, csökken a munkavállalók kapacitása, motivációja, az elvégzett munka mennyisége, roszszabb minőségű munkát adnak ki a kezükből, és kevesebb interakcióba lépnek munkatársakkal, ügyfelekkel.

Az Eurofound (2012) kutatásai szerint a menedzserek hiányoznak a legkevesebbet, ugyanakkor rájuk jellemző leginkább a presenteeism. A jelenség gyakoribb még az anyagi problémákkal küzdők, munkaalkoholisták, szellemi munkát végzők, gyermektelenek, alvási problémákkal küzdők, idősebbek, egészségtelen életvitelt folytatók között is (Garrow, 2016). A dohányzó munkavállalók körében 28 százalékkal, az egészségtelenül táplálkozók körében 66 százalékkal, a mozgásszegény életmódot folytató munkavállalók körében 50 százalékkal nagyobb az esélye a presenteeismnek, mint az egészségesen élőknél (Aldana, 2018d).

Mi áll a presenteeism mögött? Egyrészt személyes okok magyarázhatják: például azt hisszük, senki más nem képes elvégezni a munkánkat, vagy tényleg nincs, aki helyettesítsen. Idetartozik még a lojalitás (nem akarunk rosszat a kollégáknak, az ügyfeleknek, a cégnek), a munkahely elvesztésétől való félelem és anyagi megfontolás (a táppénz kevés, vagy csökken a jutalom) is. Másrészt szervezeti okok, a vállalati kultúra (a fönök bejár betegen, ezért én sem tehetem meg, hogy hiány- 
zom, a kollégák kibeszélik a távol lévőt) is vezethetnek presenteeismhez (BakerMcClearn et al., 2010).

A preseteeism mint eredményszemléletű kockázati faktor legfőbb okai (kiváltó kockázati faktorai) az allergia, a depresszió, a kiégés, a stressz vagy egyéb pszichés betegségek, a fáradtság, a cukorbetegség, a mozgásszervi panaszok, a megfázás, a fejfájás vagy bármely fertőző betegség. Ráadásul a kiváltó okok közül sok további károkat is okozhat: a beteg megfertőzheti a többieket, a különféle tünetek elvonhatják a többiek figyelmét és csökkenthetik azok munkakedvét is. A munkahelyi morál romlik, így tovább csökkenhet az összvállalati teljesítmény.

Egyes kutatások szerint a presenteeism miatti termelékenységvesztés 7,5-szer nagyobb is lehet, mint a hiányzások miatti, és háromszor többe kerülhet, mint a táppénzkiadások összege (Garrow, 2016). A különböző országokban, különböző időpontokban, különböző módszerekkel született becslések a presenteeism nemzetgazdasági költségeit a GDP alig o,2 százalékától annak több mint 3 százalékáig (DeVol-Bedroussian, 2007) terjedő intervallumban becslik. Az Egyesült Királyságban a hiányzás egy före jutó éves átlagos költsége 486 euró, míg a presenteeism költsége 895 euró.

A Virgin Pulse (2017) 17 ország 2000 munkavállalójával készített felmérésével arra jutott, hogy a felmért munkavállalók átlagosan négy napot töltenek évente betegen, de elismerték, hogy évente átlagosan 57,5 munkanapon nem teljes értékü a teljesítményük. Ugyanakkor a presenteeismmel kapcsolatos különféle adatokat érdemes óvatosan kezelni. Egyrészt általánosan elfogadott, kiforrott módszertan egyelőre nincs, a jelenség mérésére alkalmazott önbevallásos tesztek pedig a sokszor csupán néhány egyszerü állítással való egyetértést mérő Likert-skálák. Másrészt a jelenség nemcsak kultúránként, országonként és időben, de ágazatonként is jelentős eltéréseket mutathat (1. ábra). 


\section{1.ábra}

A presenteeism hatása az egyes ágazatok termelékenységére (\%, Ausztrália)

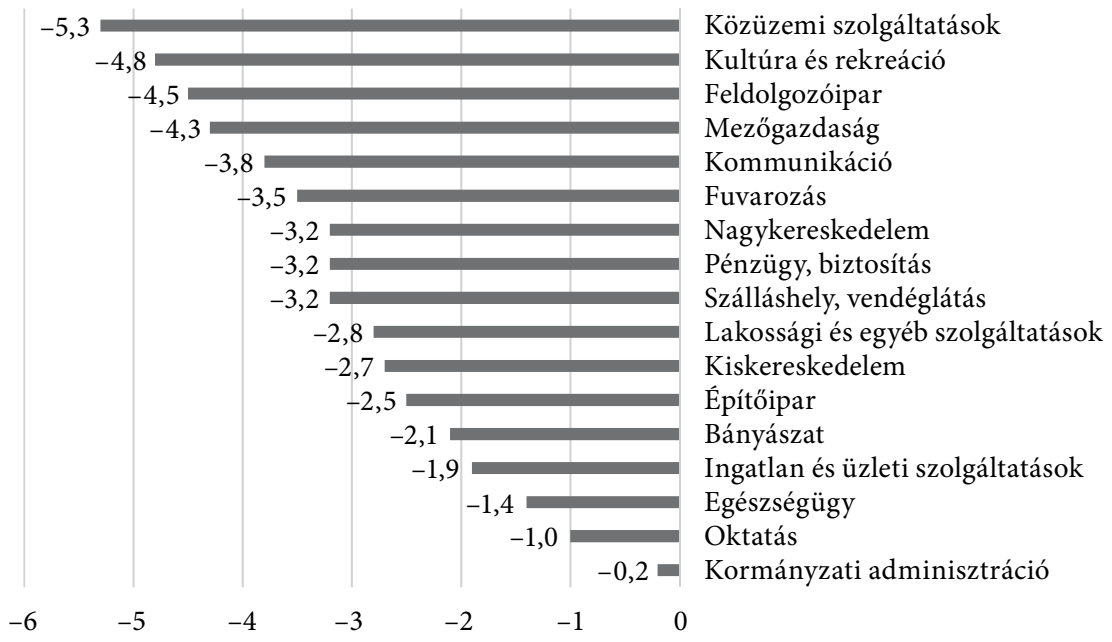

Forrás: KPMG Econtech (2011), idézi Garrow (2016)

A fizikai inaktivitás szintén számos gond forrása. Lechner (2009) 1984-2006-os német paneladatokon empirikusan bizonyította a fizikai aktivitás hatását a jövedelemre, azaz a német munkavállalóknál átlagosan havi 100 euróval nagyobb bevétellel járt együtt a szabadidős sportolás. A folyamatos testmozgás pillanatnyilag és tartósan is javítja a koncentrációs képességet és a hangulatot. Védelmi hatása is van a mozgásnak: a hippocampust és a prefrontális kérget nagyobbá és erősebbé teszi, és ezáltal megvéd olyan gyógyíthatatlan betegségektől, mint az Alzheimer-kór vagy a demencia. Mindezen jótékony hatások ellenére a 2010-es Eurobarometer-felmérés (2010) adatai szerint a magyar lakosságnak csupán 5 százaléka végzett heti öt alkalommal sporttevékenységet, de a nem napi rendszerességgel mozgók aránya is csak 18 százalék volt. Az Eurobarometer (2014) újabb, 2014-es kutatásai alapján 15 százalékra növekedett a heti öt alkalommal sportolók aránya, és 23 százalékra a valamilyen rendszerességgel mozgók aránya, de ez még mindig a 33 százalékos uniós átlag alatt maradt.

A Randstad Workmonitor kutatása (2014) szerint munkaidőben a magyarok 15 százalékának van lehetősége sportolni, de munkaidőn kívül is csak 16 százalék tudja igénybe venni a vállalat edzőtermét vagy kap kedvezményt a munkaadójától sportlétesítménybe. Ugyanez az arány Ausztriában 26, Lengyelországban 33, az Egyesült Államokban 40, Svédországban pedig 67 százalék.

A túlsúly és a helytelen táplálkozás ugyancsak sokat emlegetett egészségügyi kockázati tényező, bár az előbbi inkább más okok eredője, nem pedig önálló koc- 
kázati faktor. Túlsúlyos embereknek a 25-30-as BMI-vel rendelkező személyeket nevezik, 30 fölött pedig elhízásról beszélhetünk. 2014-ben közel 2 milliárd felnőtt ember volt túlsúlyos a világon, és további 600 millió ember elhízott. A súlytöbblettel küzdők aránya az elmúlt húsz évben megduplázódott. Évente 2,8 millió ember hal meg a túlsúly okozta szövődmények miatt, ezzel az ötödik haláloki tényezőnek számít a kövérség.

Az OECD (2017) Obesity Update 2017 tanulmánya szerint az elhízottak aránya a tagországok közül csak az Egyesült Államokban, Mexikóban és Új-Zélandon magasabb, mint Magyarországon. A jelentés alapján a 15 évesnél idősebb magyar lakosság 30 százaléka elhízott (OECD, 2017). A 15 év alatti magyar gyerekek 16 százaléka túlsúlyos, ha pedig csak a felnőtt lakosságot vizsgáljuk, az OGYÉI által készített állapotfelmérés szerint Magyarországon három felnőttből kettő túlsúlyos vagy elhízott (Polgár, 2018).

A WHO adatai szerint a cukorbetegek 44 százalékánál, az ischémiás szívbetegségek 23 százaléknál, bizonyos rákos megbetegedések 7-41 százalékánál a túlsúly és az elhízás a kiváltó ok. A magas vérnyomás, a kóros koleszterinszint, a cukorbetegség szinte egyértelműen együtt jár a túlsúllyal. A kövérség nyomán kialakuló egészségügyi problémák kezelése éves szinten összesítve 229 milliárd forintba kerülnek az államnak és az egyéneknek Magyarországon (Polgár, 2018).

A hazai egészséges táplálkozási helyzetről sokat elárul, hogy a KSH adatai szerint a 16 évesnél idősebbeknek csak a 40 százaléka fogyaszt naponta gyümölcsöt, míg friss zöldséget csupán 30 százalék. A zöldség- és gyümölcsfogyasztás szoros kapcsolatban áll az anyagi helyzettel is, a nők, a magasabb iskolai végzettségúek és a magasabb jövedelmüek gyakrabban fogyasztanak zöldséget és gyümölcsöt (Pénzcentrum, 2018).

Az alváshiány ugyancsak súlyos kockázati tényező. Alvásra az agyunknak feltétlenül szüksége van, ilyenkor távolítja el a neurális aktivitás melléktermékeit. Ha nem alszunk eleget, a megmaradt toxikus fehérjék csak útban vannak és lassítják az újabb információ feldolgozását, a problémamegoldást, megölik a kreativitást. Az alváshiány az egészségre is káros, súlyos egészségügyi problémák köthetőek hozzá, mint például a szívroham, a stroke, a 2. típusú cukorbetegség és az elhízás.

Egy kutatás szerint (The Sleep Council, 2013) a brit munkavállalók mindössze 8 százaléka ébred kipihenten, vagyis 92 százalékuk már eleve fáradtan megy be a munkahelyére. A kialvatlanság következtében kialakuló testi és lelki betegségek miatt 2016-ban, a Rand Europe statisztikai cég szerint (Rand Europe, 2016) közel 40 milliárd fonttal kevesebb GDP-t termeltek a brit munkavállalók. A Michigan Egyetem kutatása alapján (Brooks, 2015) azok a munkavállalók, akik a munkaidejük közben néha ledőlhetnek aludni vagy hosszabb szüneteket tarthatnak, egy 
idő után sokkal produktívabbak lesznek, és jobban viselik a stresszt. Ez pedig különösen igaz lehet azokra, akik valamiért nem képesek végigaludni az éjszakát. Az egyes egészségügyi kockázatok és a termelékenység közötti kapcsolatot sok szempontból vizsgálták már. O’Donnell (2000) humánteljesítmény-modellje szerint a munkavállalók teljesítménye magasabb, amikor fizikailag és érzelmileg is jól vannak, és szeretnek is dolgozni. Ez kevesebb hiányzáshoz és preseteeismhez is vezet, ami javítja a teljesítményt. Aldana (2001) eredményei szerint az összes egészségügyi rizikótényező közül a túlsúly és a stressz az a két faktor, amelyek növekedése kétségtelenül növeli az egészségügyi kiadásokat és a hiányzásos napok számát.

Boles et al. (2004) ugyanakkor 11 egészségügyi kockázatot vizsgált: helytelen táplálkozás, BMI, magas koleszterinszint, fizikai inaktivitás, stressz, orvosi látogatások, érzelmi hiány, magas vérnyomás, dohányzás, cukorbetegség/magas vércukorszint és alkoholfogyasztás (ezeket szokták jellemzően vizsgálni az egyes kutatásokban). Eredményeik szerint a több kockázati tényezővel rendelkező résztvevők nagyobb termelékenységi veszteséget szenvedtek el. A termelékenységi veszteség esélye a cukorbetegek (hiányzás) és a stressz (preseteeism) esetében volt a legmagasabb. A kockázatok miatti realizált veszteség több mint 67 dollár volt személyenként egy egyhetes vizsgált időszakban. Pelletier et al. (2004) arra jutott, hogy ha egy munkavállaló egészségügyi kockázatainak a száma eggyel kevesebb, a hiányzása 2 százalékkal csökken, a presenteeism pedig 9 százalékkal. Burton et al. (2006) ugyancsak kimutatta, hogy a kockázati tényezők számának növekedése a presenteeism növekedésével jár együtt.

Vaughan-Jones és Barham (2009) szerint azon munkavállalók, akik a közepes vagy magas kockázati csoportba tartoznak az étkezést vagy mozgást tekintve, 6-12 százalékkal alacsonyabb teljesítményt nyújtanak, mint alacsony kockázatú társaik. Lenneman et al. (2011) megerősítették, hogy azon munkavállalóknál, akiknél az egészségügyi kockázatok csökkentek, az egészség javult, a termelékenység romlása is csökkent. Már az csökkentette a termelékenységveszteséget, ha valaki a magas kockázatú csoportból az alacsonyabba került át fizikai inaktivitás, stressz, depresszió vagy testsúly tekintetében.

Goetzel et al. (2012) rámutattak: olyan kockázati tényezők okozzák a vállalati egészségügyi kiadások több mint 20 százalékát, amelyeken lehetne változatni: depresszió, magas vércukorszint, magas vérnyomás, elhízás, dohányzás, fizikai inaktivitás, stressz. Merrill et al. (2013) szerint azok, akik legalább 30 percet mozogtak minimum heti három napon és öt vagy annál több alkalommal gyümölcsöt és zöldséget fogyasztottak a megelőző négy napban, 1,2-szer nagyobb valószínüséggel nyújtottak nagyobb teljesítményt azoknál, mint akik ezt nem tették.

Kirkham et al. (2015) egy négyéves periódus (2007-2010) során 17089 munkavállaló kockázatértékelését végezték el. Eredményeik szerint az érzelmi egész- 
ség, a nem megfelelő testmozgás, a dohányzás és a testtömegindex (BMI) 35 éves korban következetesen összefüggésbe hozható mind a hiányzással, mind a preseteeismmel. A magas vérnyomás, a vércukorszint, a nem megfelelö testmozgás és az alkoholfogyasztás összefüggésben állt az idősebbek hiányzásával és nem teljes értékű munkavégzésével. A termelékenység csökkenése leginkább az érzelmi egészséghez és az elhízáshoz kapcsolódik.

Hayman (2016) elemzései azt mutatták, hogy a testmozgás, a dohányzás, a testtömegindex (BMI) és a táplálkozás szignifikáns összefüggést mutat a munkahelyi termelékenységgel. A testmozgás és a táplálkozás szignifikáns pozitív kapcsolatot mutatott a munkahelyi termelékenységgel, míg a dohányzás és a BMI növekedése negatívan korrelált a munkahelyi termelékenységgel. A regresszióanalízis eredményei szerint a termelékenység 21 százalékáért ezek a változók a felelősek.

A WHAA (2016) szerint a magas kockázatú alkalmazottak (5+ kockázat) a munkaidejük 32,7 százalékában nem termelékenyek és havonta átlagosan 5,1 órát hiányoznak, az alacsony kockázatú alkalmazottak (o-2 kockázat) munkaidejük 14,5 százalékában nem termelékenyek és csak 2,4 órát hiányoznak havonta. Az egészséges és az egészségtelen munkavállalók közötti termelékenységi különbség tehát 18,2 százalék, munkanapra lefordítva évente 45 munkanap. A hiányzás és a preseteeism egy része (lásd 3. és 4. táblázat) különböző egészségügyi és életviteli faktoroknak tulajdonítható. A nagyobb egészségkockázatú munkavállalók többet hiányoznak, és termelékenységük is alacsonyabb.

\section{3. táblázat}

A kockázati tényezők hozzájárulása a hiányzáshoz és a preseteeismhez

\begin{tabular}{lccc}
\hline Kockázati tényezók & Hiányzás & Presenteeism & Összesen \\
\hline 2-es típusú cukorbetegség & $4,94 \%$ & $18,26 \%$ & $23,2 \%$ \\
Depresszió & $2,61 \%$ & $14,51 \%$ & $17,12 \%$ \\
Alkoholfogyasztás & $5,00 \%$ & $4,78 \%$ & $9,78 \%$ \\
Elhízás/Túlsúly & $1,40 \%$ & $8,30 \%$ & $9,70 \%$ \\
Magas koleszterinszint & $3,14 \%$ & $4,91 \%$ & $8,05 \%$ \\
Dohányzás & $2,84 \%$ & $4,78 \%$ & $7,62 \%$ \\
Krónikus stressz & $3,08 \%$ & $4,45 \%$ & $7,53 \%$ \\
Asztma & $4,80 \%$ & $1,20 \%$ & $6,00 \%$ \\
Migrén & $3,96 \%$ & $1,99 \%$ & $5,95 \%$ \\
Fizikai inaktivitás & $0,28 \%$ & $4,59 \%$ & $4,87 \%$ \\
\hline
\end{tabular}

Forrás: WHAA (2016) 


\section{4. táblázat}

A hiányzás és a termelékenység kapcsolata a munkavállalói kockázati szinttel

\begin{tabular}{lcc}
\hline Kockázat & $\begin{array}{c}\text { Hiányzásos napok } \\
\text { átlagos éves száma }\end{array}$ & $\begin{array}{c}\text { Nem termelékeny napok } \\
\text { átlagos éves száma }\end{array}$ \\
\hline Alacsony (0-2 tényező) & 1,6 & 5,1 \\
Közepes (3-4 tényező) & 2,4 & 12,9 \\
Magas (5+ tényező) & 3,6 & 28,9 \\
\hline
\end{tabular}

Forrás: WHAA (2016)

Az 5. táblázatban a kockázati tényezőkről szóló kutatások tapasztalatait összegezzük. Úgy tünik, a termelékenységet leginkább a fizikai inaktivitás, a stressz és az elhízás (magas BMI, helytelen táplálkozás) csökkenti. E területekre kell tehát a leginkább koncentrálni, amikor egy vállalat egészségprogramot indít.

\section{5. táblázat}

A termelékenységet csökkentő legfontosabb kockázati tényezők

\begin{tabular}{|c|c|c|c|c|c|c|c|c|}
\hline & 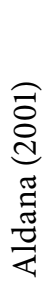 & 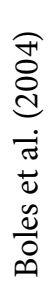 & 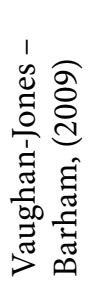 & 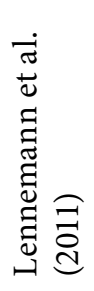 & 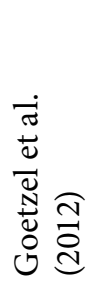 & 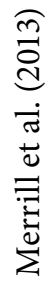 & 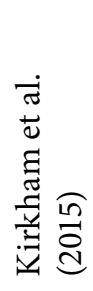 & 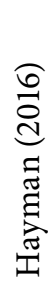 \\
\hline Fizikai inaktivitás & & & $\mathrm{x}$ & $\mathrm{x}$ & $\mathrm{x}$ & $\mathrm{x}$ & $\mathrm{x}$ & $\mathrm{x}$ \\
\hline Stressz & $\mathrm{x}$ & $\mathrm{x}$ & & $\mathrm{x}$ & $\mathrm{x}$ & & $\mathrm{x}$ & \\
\hline Elhízás/BMI & $\mathrm{x}$ & & & $\mathrm{x}$ & $\mathrm{x}$ & & $\mathrm{x}$ & $\mathrm{x}$ \\
\hline Helytelen táplálkozás & & & $\mathrm{x}$ & & & $\mathrm{x}$ & & $\mathrm{x}$ \\
\hline Dohányzás & & & & & $\mathrm{x}$ & & $\mathrm{x}$ & $\mathrm{x}$ \\
\hline Vércukor & & $\mathrm{x}$ & & & $\mathrm{x}$ & & $\mathrm{x}$ & \\
\hline Vérnyomás & & & & & $\mathrm{x}$ & & $\mathrm{x}$ & \\
\hline Depresszió & & & & $\mathrm{x}$ & $\mathrm{x}$ & & & \\
\hline Alkoholfogyasztás & & & & & & & $\mathrm{x}$ & \\
\hline
\end{tabular}

Forrás: saját szerkesztés 


\section{A SIKERES MUNKAHELYI EGÉSZSÉGPROGRAMOK FELÉPÍTÉSE}

Mint minden kockázatkezelési rendszernél, a munkahelyi egészségprogramoknál is a helyzet feltérképezésével kell kezdenünk. A munkavállalók egészségi állapotát és a kockázati tényezőket egy HRA (health risk assessment - egészségügyi kockázati felmérés) -kérdőívvel mérhetjük fel. A HRA (Mills, 2005) az egyénektől gyüjt információkat, s nemcsak a kockázati tényezőket azonosítja, de személyre szabott visszacsatolást is biztosíthat. Mivel a kockázatok egy részét éppen a dolgozó okozza valamilyen nemkívánatos viselkedésével (felelőtlen közlekedés, dohányzás, alkohol- és drogfogyasztás) vagy éppen a kívánatos cselekvés elhanyagolásával (mozgás, egészséges táplálkozás), a felmérés puszta ténye, illetve az eredmények szakértővel való kiértékelése önmagában egyfajta kockázatkezelési eszköz, hiszen csökkentheti a kockázatok valószínűségét. Ugyanilyen befolyásolásra építenek a munkavédelmi oktatások is, ám ott rendszerint nem történik adatgyüjtés.

Egy tipikus HRA-kérdőív információt gyüjt a demográfiai jellemzőkről (nemről, életkorról), életmódról (dohányzás, testmozgás, alkoholfogyasztás, étkezés, gyógyszerszedés, alvási szokások, stressz), személyes és családi kórtörténetről (öröklött hajlamok, oltások). Bizonyos esetekben fiziológiai adatokat (magasság, testsúly, vérnyomás, koleszterinszint) is gyüjtenek. A HRA-módszert rendszerint azért kritizálják, mert a kérdőívek túl hosszúak (alacsony teljes kitöltöttség), önbevallásra építenek (tévedések, torzítások), önkitöltősek (félreértések), az adatfelvételnek sokszor nincs gyakorlati haszna (az adatokat senki sem elemzi, nincsen változáskövetés vagy visszacsatolás), a személyes adatok védelme nem mindig biztosított (illetéktelen hozzáférés, munkáltatói büntetés a problémákat őszintén vállalóknak), és nem feltétlen indukálnak változást (sem a munkáltató, sem a munkavállaló viselkedése nem változik meg).

A sikeres vállalati egészségprogramokhoz a legfontosabb érintetteket és a véleményvezéreket kell megnyerni (WHO, 2010). Jól tetten érhető a párhuzam az ugyancsak a vállalati kultúrába való integrálódást igénylő kockázatkezelési (enterprise risk management - ERM) programok tapasztalataival (Oliveira et al., 2018). Ezen felül ugyanúgy szükség van a felső vezetők támogatására és egy irányító csapatra. Nekik kell kialakítaniuk a szervezeten belül a megfelelően támogató környezetet, átadni a szükséges információkat, ösztönözni és képezni a potenciális résztvevőket. Akár az ERM-rendszereknél, itt is fel kell mérni a kiindulási állapotot (orvosi vizsgálatok, tesztek, kérdőívek, statisztikák).

Ki kell jelölnünk a célt is. El kell dönteni, mely területekre fókuszálunk elsősorban, figyelembe véve nemcsak a kezelendő kockázatokat, de a program várható költségeit és eredményeit is. A 3-5 évre szóló stratégiai tervet le kell bontani éves programokra. Akár az ERM müködtetésénél, a célokat, eszközöket, folyamatokat, felelösöket, illetve az idő- és költségkeretet is rögzíteni kell. 
A végrehajtás során a résztvevők általában folyamatos támogatást igényelnek, és szükség van rendszeres visszacsatolásra is. A sikerhez ne csak nyomon követtessük a változást, de rendszeresen osszuk is meg a résztvevőkkel, milyen nagyra értékeljük erőfeszítéseiket. Az eredményesség és a változó körülmények ismeretében a tapasztalatokat összegezve rendszeresen újra kell gondolni a programot (WHO, 2010), pontosan úgy, ahogyan ezt az ERM-rendszernél is megszokott (International Organization for Standardization, 2018).

\section{AZ EGÉSZSÉGPROGRAMOK HATÁSAI}

Az egészségvédelmi irányelveknek való megfelelés a kkv-knek a legnehezebb. Az uniós vállalkozások 93 százaléka mikrovállalkozás, és ezeknek csak 69 százaléka végez rendszeres kockázatértékelést, míg a nagyobb vállalkozásoknál ez az arány 96 százalék (Dabrónaki, 2017). A Xerox (2016) adatai szerint globálisan 2008-ban a multinacionális vállalatok 34 százaléka indított egészségprogramokat, 2014-ben már 56, 2016-ban 69 százalékuk. A vállalatok egészségfejlesztési ráfordításai 2018ban nemzetközi szinten fejenként évi 150 és 1200 dollár között mozogtak (Aldana, 2018a). Ezek az egészségprogramok négyféle módon is értéket teremthetnek a vállalatnak:

1) a programok javítják az alkalmazottak egészségtudatosságát,

2) növelik a termelékenységet (csökkentik a hiányzást és a presenteeism jelenségét),

3) kisebb lesz a fluktuáció,

4) javul a dolgozók morálja, a munkahelyi hangulat is (Aldana, 2018b; 2018c).

Ugyanakkor ezek a programok időigényesek. Nemzetközi kutatások eredményei alapján (6. táblázat), ha a vállalat elindít egy mozgásprogramot, amelynek keretében a kollégák együtt sportolnak, már néhány hónapon belül is megváltozhat a munkahelyi légkör, a csapat összetartóbb lesz, nő az elköteleződés. Ugyanakkor magasabb teljesítmény, termelékenység csak az indulás után 1-2 évvel lesz mérhető, s csak ekkor indul meg a vállalati imázs pozitív változása és a munkavállalók testi-lelki egészségtudatosságának és elégedettségének mérhető növekedése. Ekkortól érezhetően csökken a fluktuáció is. Ugyanakkor nagyjából 3-5 év kell ahhoz, hogy a munkahelyi sérülések, balesetek, betegségek, hiányzások, valamint a presenteeism látványosan csökkenjen, és az emberekbe fektetett képzési, fejlesztési kiadások is megtérüljenek (Tasmania, 2012). 
6. táblázat

A munkahelyi mozgásprogramok hatásai

\begin{tabular}{|c|c|c|}
\hline $\begin{array}{l}\text { Néhány hónapon } \\
\text { belül }\end{array}$ & 1-2 év alatt & 3-5 év után \\
\hline $\begin{array}{l}\text { Szorosabb } \\
\text { elköteleződés }\end{array}$ & $\begin{array}{l}\text { Magasabb termelékenység } \\
\text { és teljesítmény }\end{array}$ & $\begin{array}{l}\text { Kevesebb } \\
\text { munkahelyi sérülés }\end{array}$ \\
\hline $\begin{array}{l}\text { Jobb munkahelyi } \\
\text { morál }\end{array}$ & $\begin{array}{l}\text { Megnövekedett } \\
\text { munkaerö-megtartás } \\
\text { és vonzás }\end{array}$ & $\begin{array}{l}\text { Ritkább betegség, } \\
\text { hiányzás }\end{array}$ \\
\hline \multirow[t]{3}{*}{$\begin{array}{l}\text { Erősebb csapatszellem, } \\
\text { közösségformálás }\end{array}$} & Pozitív imázs & $\begin{array}{l}\text { Kevesebb } \\
\text { presenteeism }\end{array}$ \\
\hline & $\begin{array}{l}\text { Jobb egyéni } \\
\text { egészségtudatosság }\end{array}$ & $\begin{array}{l}\text { A képzések, fejlesztések } \\
\text { javuló hozamai }\end{array}$ \\
\hline & Nagyobb elégedettség & \\
\hline
\end{tabular}

Forrás: Tasmania (2012, p. 15.)

Az általános empirikus tapasztaltok összegzésén túl természetesen explicit mérési megközelítéseket is találunk a szakirodalomban. Ezek közül három szemlélet elterjedt. Koncentrálhatunk (1) a munkaadónál jelentkező, pénzben jól mérhető előnyökre (ROI-szemlélet), (2) vizsgálhatjuk az egyének és csoportok szintjén megjelenő, sokszor szubjektív és nehezen mérhető változásokat is (VOI-szemlélet), vagy (3) becsülhetjük a társadalom számra elérhető előnyöket is (SROI).

Miközben a ROI-szemléletet követő vállalat csak azt figyeli, hogy az egészségfejlesztésbe befektetett tőke számára milyen pénzbeli hozamokat eredményez, addig a VOI-szemléletű vállalkozás az értékteremtő (egészségfejlesztési) tényezők változását méri. A VOI-szemléletben a mérés problémája fokozottan jelentkezik, hiszen az egyszerűen mérhető baleseteken, a hiányzásos napok számán, az egészségügyi költségeken túl nyomon kell követni például az alkalmazottak morálját, elköteleződését és jóllétét is. E megközelítésnél már fokozottan jelentkezik a személyes adatok védelmének kérdése, hiszen még anonimizálás után is felismerhető lehet az egyén egy kisebb szervezeti egységben.

Az egészségügyi költség-haszon elemzésekből kifejlődött SROI-szemlélet az egész társadalmat tekinti érintettnek, ám szinte kizárólag pénzbeli mérésre törekszik. A nagyobb haszonélvezői kör figyelembevétele miatt itt a ROI-nál jóval magasabb megtérülés mutatható ki, viszont súlyos etikai problémákkal is szembesülhetünk egyes mennyiségek (emberi élet, betegségek elkerülése, gyógyítása, termelékenységi ráta növekedése) pénzbeli mérésekor. A 7. táblázat pedig a ROI-szemlélet 
jegyében a nemzetközi kutatások, metaanalízisek eredményei alapján mutatja be, hány dollárt takaríthat meg a vállalat, ha 1 dollárt egészségfejlesztésre költ.

7. táblázat

Becsült ROI-értékek (befektetett dolláronként)

\begin{tabular}{lccc}
\hline Forrás & $\begin{array}{c}\text { Egészségügyi } \\
\text { kiadások }\end{array}$ & $\begin{array}{c}\text { Hiányzás } \\
\text { miatti kiadások }\end{array}$ & $\begin{array}{c}\text { Teljes } \\
\text { megtakarítás }\end{array}$ \\
\hline Aldana (2001) & 3,48 & 5,82 & 4,30 \\
Goetzel et al. (2008) & 3,27 & $\begin{array}{c}1,40-4,70 \\
\text { (3 éves időtávon) }\end{array}$ \\
Baicker et al. (2010) & $(2-3$ éves időtávon) & $(2-3$ éves időtávon) & \\
Dongen et al. (2011) & $1,40-4,60$ & 2,70 & 3,92 \\
Henke et al. (2011) & & & $\begin{array}{c}(2002-2008 \text { között) } \\
\text { Baxter et al. (2014) }\end{array}$ \\
$\begin{array}{l}\text { Amerikai Kereskedel- } \\
\text { mi Kamara (2017) }\end{array}$ & & $\begin{array}{c}1,50-3,00 \\
\text { (2-9 éves időtávon) }\end{array}$ \\
\hline
\end{tabular}

Forrás: saját szerkesztés

A munkahelyi egészségfejlesztés hatásait itthon csak kevesen vizsgálták, mivel az ilyen programok csak az utóbbi években kezdtek elterjedni. Egy 709 régiós vállalatot (ezek harmada magyar cég volt) felmérő MGYOSZ-kutatás (2010) szerint a munkahelyi egészségvédelem területén az ergonómiai fejlesztések domináltak (32 százalékban), a cégek több mint 40 százalékánál pedig semmilyen egészségfejlesztési program sem működött. A Szinapszis (2013) kutatása szerint a megkérdezett 400 hazai munkavállalónak csupán 17 százaléka vett részt rendszeres és kötelező munkahelyi egészségprogramban.

\section{HAZAI TAPASZTALATOK}

Empirikus vizsgálatunk a Legfittebb Munkahely Felmérés (LFM) eddigi öt hullámának győzteseivel a díjátadókon készített interjúkra, négy győztessel készített mélyinterjúkra, valamint egy 2015 márciusában megtartott workshop tapasztalataira épül. Ezek során több más téma mellett a sikeres hazai programok jellemzőit 
és hatásait, a fontosabb kockázati tényezőket is áttekintettük a felmérés érdeklődő résztvevőivel és győzteseivel. A díjátadókon valamennyi díjazottat (az elmúlt öt év alatt 14 győztes volt, lásd 8 . táblázat) megkérdeztük, mi a programjuk sikerének titka, és milyen hatásokat tapasztalnak.

Az LFM online része a munkavállalók szokásai mellett a vállalati egészségtámogatás módjait és az ezekkel való elégedettséget is feltérképezi, ezen kérdéscsoportok elemzése alapján választották ki a győzteseket. A felmérés és a díj nemcsak elismeri a dolgozók egészségéért, mozgásáért aktív szerepet vállaló hazai vállalatokat, de ösztönzi is az egészség- és mozgásprogramokat, és lehetőséget biztosít arra, hogy a vállalatok egymástól a legjobb gyakorlatokat eltanulják. E felmérésben jellemzően azok a vállalatok képviseltetik magukat, amelyek az átlagnál többet tesznek a munkavállalóik egészsége, mozgása érdekében. A győztesek pedig messze a hazai átlag felett állnak, vagyis az általuk leírt helyzet sokkal kedvezőbb, mint ami egy tipikus munkahelyen tapasztalható.

\section{8. táblázat}

Interjúalanyok (a Legfittebb Munkahely Felmérés győztesei)

\begin{tabular}{|c|c|c|c|c|}
\hline & Kisvállalat & Középvállalat & Nagyvállalat & Államigazgatás \\
\hline 2013 & Hansgrohe Kft. & GE-Healthcare & HPE & - \\
\hline 2014 & SZ+C Stúdió Kft. & $\mathrm{HBO}$ & Unilever & $\begin{array}{c}\text { Kancellária } \\
\text { Sportegyesület }\end{array}$ \\
\hline 2015 & - & $\mathrm{HBO}$ & Unilever & $\begin{array}{c}\text { NGM } \\
\text { Sportegyesülete }\end{array}$ \\
\hline 2016 & $\begin{array}{c}\text { BAT Pécsi } \\
\text { Dohánygyár Kft. }\end{array}$ & $\mathrm{HBO}$ & Diageo & $\begin{array}{c}\text { Kancellária } \\
\text { Sportegyesület }\end{array}$ \\
\hline 2017 & $\begin{array}{c}\text { Evopro } \\
\text { Cégcsoport }\end{array}$ & Tigra Kft. & $\begin{array}{c}\text { Contitech } \\
\text { Rubber Industrial }\end{array}$ & $\begin{array}{c}\text { Nemzeti } \\
\text { Választási Iroda }\end{array}$ \\
\hline
\end{tabular}

Forrás: saját szerkesztés

A Legfittebb Munkahely díjazottjaival készült interjúk feldolgozása alapján a vállalati egészségfejlesztés Magyarországon gyerekcipőben jár: a nemzetközi programokhoz hasonló komolyabb programot mindössze három vállalatnál azonosítottunk (Unilever, HPE, HBO; az Unilever kiemelkedő), a kockázatok előzetes felmérésére és a hatások mérésére pedig egyetlen vállalatnál figyelnek komolyan (Unilever). A díjazottak közlése alapján maguk is a következő céllal indultak a versenyen: 
1) visszajelzést, megerősítést kapjanak arról, hogy jó úton járnak,

2) a vállalaton belül is elinduljon egy diskurzus az egészségfejlesztés további fejlesztéséről, továbbgondolásáról,

3) betekintést kapjanak mások gyakorlatába, és egymástól tanuljanak.

A következőkben először azt vizsgáljuk, hogy mitől működik jól egy egészségprogram, majd összefoglaljuk, milyen hatása van az egészségprogramnak, milyen értéket teremt, és ezt hogyan mérik.

A sikertényezőket vizsgáló kérdésnél az elmélet és a gyakorlat találkozott, hiszen az elméleti részben bemutatott sikertényezők szinte egytől egyig felbukkantak. A felső vezetésnek elkötelezettnek kell lennie az egészségfejlesztő program mellett, a programnak pedig kellöképpen fontosnak kell lennie stratégiai szempontból. Ha megvan a felső vezetői elköteleződés, akkor az anyagi és emberi erőforrások biztosítása is megoldott. A vezetőknek a vállalati kultúra megváltoztatásában is fontos szerepük lehet. Szerencsés esetben a vállalati misszióba, vízióba, policybe is bekerül az egészségprogram fontossága. A válaszadók megfogalmazása szerint: „Minden a felső vezetön múlik. Ha ö szerelmes lesz ebbe, akkor minden OK.” „Nálunk is kellett jó pár év, míg a felső vezetök komolyan vették.”

Szükség van reális célokra, s arra, hogy a résztvevők tudják, honnan hová akarnak eljutni egyénileg és vállalati szinten is. Ismerni kell a kiindulási állapotot, és terveket kell készíteni (idő, pénz, emberek). „A közös cél nagyon fontos.” „Hol vagyok most, hová akarok eljutni, mi a cél, ezt tudjam, rövid és hosszú távon is, és azt is, azt hogyan, mi módon akarom elérni."

A sikeres program minden esetben hosszú távú. „Ki kell tartani a programmal, mert nem egyik pillanatról a másikra költözik be a falak közé, évek kellenek.”

Emellett talán az egyik legfontosabb az igények felmérése, a munkavállalók bevonása: „A munkavállalót már a legelején be kell vonni, és aztán végig figyelembe kell venni. És hadd jelezzen vissza.” „Az alulról jövö kezdeményezésekre kell figyelni.” „Az igények sokszinüségét próbáljuk lefedni.”

Az igények felmérése mellett egy jól müködő programnál végeznek állapotfelmérést (milyen az alkalmazottak testi-lelki állapota, hogyan táplálkoznak, mennyit mozognak, mennyit hiányoznak), és egyénileg kiértékelik az állapotfelméréseket, készítenek egy személyes fejlesztési tervet (ajánlást) az egészség-rizikófaktoroknak és igényeknek megfelelően. Ezen egyéni felmérésekre lehet építeni a vállalati programokat is. (Ez egyetlenegy vállalatnál valósul meg profi szinten.)

Mindenütt vannak felelősök, egy csapat (vagy sok esetben egyetlen ember), amely/aki a munkahelyi egészségfejlesztő programért, annak a működéséért felelős minden síkon. Vannak egészségfejlesztő megbeszélések, meetingek, ezeken minél több részleg képviselőinek kell részt vennie. „Mindenhol kell egy helyi 
csapat.” "Kell egy ikon, aki az egésznek a lelke.” „Kell egy motor, aki elkötelezett, lelkes, leleményes, és szándéka jól csinálni.”

Az egyes eseményeket, előadásokat, programokat több csatornán is megosztják a résztvevőkkel. Motiválják, ösztönzik az alkalmazottakat, hogy minél több eseményen, programon vegyenek részt. Megfelelő kommunikációs csatornákat választanak, ahol az előnyök, motiválók mellett van lehetőség munkavállalói visszajelzésre, elégedettség (elégedetlenség) kifejezésére is. Lehet különféle marketingeszközöket is használni, de a tudományos tények, bizonyítékok is hatásosak. Formális és informális csatornákat is használni kell. „Hozzám bármikor jöhetnek, de anonim módon is van lehetőség visszajelezni."

A hatások értékelése, mérése, bár itt a lista legvégére került, talán a legfontosabb elem. „A legfelsőbb vezetés meggyözésére a mérhetőség egy kulcs. Ezzel lehet elérni, hogy komolyan vegyék. Nekik számok kellenek." Ha mérnek, akkor tudnak folyamatosan értékelni, ellenőrizni, fejleszteni a programon is. Elméletben mindenki fontosnak tartja, ugyanakkor csupán egyetlen győztes vállalatnál van nagyon jól kidolgozott mérési rendszer, ők tudtak pontos számokat is mondani.

Náluk éves szinten 3,9 napra csökkent az egy munkavállalóra jutó átlagos hiányzás, miközben az országos átlag 8 nap volt, valamint a ROI-szemlélet jegyében, a programba 1 forintot fektetve 3,73 forintnyi hozam keletkezett. Ök még a presenteeismet, sőt az elégedettséget is mérik. Máshol nem találkoztunk konkrét számokkal, nem tudták megmondani, milyen a program megtérülése. „Nehéz visszamérni.” „Mi ebben nem voltunk elég tudatosak, pedig fontos lenne mindent mérni.” A nyilatkozók sokszor maguk is az „érzés” szót használták, vagyis a hiányosságnak tudatában vannak. A „Milyen hatása van az egészségprogramnak, milyen értéket teremt?” kérdésre számtalan tényezőt fel tudtak sorolni, de csak személyes benyomások alapján.

A betegnapok számának csökkenése több helyen is előkerült. A mozgás, az egészséges életmód csökkenti a hiányzást, ezt a nemzetközi szakirodalmakhoz hasonlóan a magyar gyakorlat is megerősítette: „A helyes életmódot folytató dolgozók esetében a betegszabadságok száma is jóval alacsonyabb.” „Az egészség és a kiegyensúlyozott életvitel a betegszabadságok minimálisra redukálásának feltétele.” „Mi nem mérünk, de látjuk, hogy a dolgozóink elégedettebbek és jobb fizikai állapotban vannak, és kevesebbet vannak betegszabadságon.” „Nálunk semmi mást nem mérünk, csak a hiányzásos napok számát, az tényleg kevesebb lett."

A VOI-szemlélet is előkerült, bár magát a kifejezést - „value of investment” senki nem használta, sőt még az értékteremtés kifejezés sem hangzott el. A gyakorlatban is tapasztalták, hogy az egészségprogramoknak hála, növekszik a dolgozók egészségtudatossága, így csökken az egészségkockázatuk, legyen szó akár dohányzásról, akár mozgásról, akár lelki tényezőkről. „Nálunk nőtt a sportolók 
aránya, csökkent a dohányzók száma, a lelki tényezőket nézve a pozitív gondolkodás erösödött.” „Életmódváltásokat értünk el, erre büszke vagyok.”

Ezen egészségprogramokkal növelhető, javítható a termelékenység, az üzleti teljesítmény, és ezt ki is tudták mutatni annál a hazai győztes vállalatnál, ahol nagyon jó mérési rendszer van. „A mentális egészség és a pénzügyi teljesítmény között is ki tudunk mutatni kapcsolatot." A többi cégnél ugyan számokban kifejezett bizonyítékkal nem találkoztunk, mégis azt érzik (vagy mérés híján hiszik), hogy az egészséges munkavállalók hatékonyabbak, termelékenyebbek, kreatívabbak. „A fizikai jóllét kihat a szellemi teljesitőképességre, a mindennapi munkában, munkateljesítményben érezzük.” „A munkavállalók jó egészségi állapota biztosan serkentőleg hat a cég gazdasági növekedésére.” „Ha a munkavállalók testileg és szellemileg is egészségesek, akkor a mindennapokban is lelkes, együttmüködö és kreatív munkát tudnak végezni. Nemcsak a kollégák profitálnak a vállalati sportos élet élénkitéséböl, hanem a cég számára is többszörösen megtérül ennek támogatása.” „A kollégák motiváltabbak, pihentebbek és így produktívabbak."

A morált, a hangulatot, a munkahelyi kapcsolatokat, a csapatépítést is többen említették. Érezhetően javult a munkakedv, a csapatmunka, az együtt dolgozás zökkenőmentesebbé vált, tényleges közösségek formálódtak. Mindezek a teljesítményt is befolyásolhatják. E megállapítások a HR-vezető vagy épp a sportért felelős kolléga „érzései”, benyomásai, aki nem feltétlenül elfogulatlan. Többször előkerült: ezeket a „soft” elemeket nehéz mérni, értékelni (a nemzetközi irodalomban sincs erre kidolgozott módszertan). „Szorosabbá váltak a munkahelyi kapcsolatok, ami a munkahelyi morál és a teljesítmény emelkedéséhez vezetett." „A hangulaton is meglátszik.” „Közösségépités a fó cél, az egyik fö motiváció és fö nyereség.” „...a házibajnokságban mindenki lelkesen részt vesz, igazi csapatösszehozó.” „De nehéz mérni ezeket.”

A mai helyzetben a munkatársak megtartása, a fluktuáció csökkentése tényleg fontos hozadéka ezen programoknak, ahogy az elégedettség, a kreativitás és a munkavállalók számára pedig a külső megjelenés is. Jó ötlet az elégedettség mérésére a Happy-or-Not alkalmazás használata: „Munkatársaink lojálisabbak, kreatívabbak, nem utolsó sorban pedig csinosabbak lettek.” „Szívesebben jártak be, elégedettebbek, mosolygósabbak lettek.” „Négy fejjel, a nagyon szomorútól nagyon boldogig fejezhetik ki a kollégák, mennyire elégedettek, nagyon népszerü ez az alkalmazás.” A Legfittebb Munkahely Felmérés kérdőíves adatai szerint a sportolásra motiváló tényezők itthon is a szakirodalomban megtalálható tényezők: az egészség, a kisebb stressz, a kikapcsolódás, a kinézet. Az LFM sajátossága, hogy itt az össztársadalmi átlagoknál hangsúlyosabban szerepelt az előnyösebb testkép, a jó kinézet és a stressz levezetése.

Van három olyan, a nemzetközi szakirodalomban feltárt tényezö, amely egyáltalán nem fordult elő a hazai interjúkban pozitív hatásként: az energiaszint, a 
biztonság és az általános jóllét növekedését senki sem említette. Mindazonáltal nagyon jó eredmény, hogy az összes többi tényezőt azonosították és érzékelték az interjúalanyok.

A kockázati tényezőket tekintve a fizikai inaktivitás, a lelki egészség/stressz és a dohányzás került elő az interjúk során. Legtöbbször az előző két tényezőt emlegették, ami egybevág a nemzetközi szakirodalom tapasztalataival is. Ezt ugyan a magyar interjúalanyok is érezni vélik, ám mérésekkel - egy vállalatot kivéve - nem igazolták.

\section{6. ÖSSZEGZÉS}

A munkavállalók egészségügyi problémái, testi-szellemi jólléte közvetlen hatással van termelékenységükre, hatékonyságukra, s így az őket foglalkoztató vállalatok teljesítményére is. Éppen ezért a munkaadóknak is érdeke, hogy támogassák dolgozóikat egészségük megőrzésében és egészségügyi problémáik megoldásában. A vállalati egészségprogramok éppen erre kínálnak eszközt: a működési kockázatok egy maghatározott körét képesek hatékonyan orvosolni.

A korábbi kutatások azt mutatták, hogy bizonyos kockázati tényezők és a munkavégzési hatékonyság között szoros kapcsolat van, amelyet nemzetközileg is egyre több társaság ismer fel. A munkahelyi egészségprogramok bevezetésében a multinacionális cégek az élen járnak. A legfontosabb kockázati tényezők a fizikai inaktivitás, a stressz, az elhízás, a helytelen táplálkozás, a dohányzás, a vércukor, valamit a magas vérnyomás mellett a depresszió és az alkoholfogyasztás.

$\mathrm{Az}$ egészségprogramoknál lényegében ugyanúgy kell eljárnunk, mint amikor komplex vállalati kockázatkezelési programot (ERM) indítunk és müködtetünk. Ugyanakkor különleges kihívásokat jelenthet a személyes adatok védelme és az olyan etikai problémák, mint a különféle egészségügyi problémák prioritásának és a dolgozói igények rangsorolásának a megállapítása. Így előfordulhat, hogy pusztán pénzügyi elveket követve éppen a legrászorultabbak maradnak ki a megcélzott körből.

Ami a programok hatékonyságát illeti, elmondható: legalább három különböző szemléletben (ROI, VOI, SROI) közelíthetünk eredményességük megítéléséhez. Noha nem létezik még kellően megalapozott, széles körben elfogadott, egységes módszertan, a leegyszerüsített becslések jellemzően azt mutatják, hogy a dolgozói egészségügyi kockázatokat pénzügyi értelemben is hatékonyan lehet kezelni különféle vállalati egészségprogramok müködtetésével.

Az egészségprogramok bevezetésében élenjáró 14 hazai cég képviselőivel készített interjúk alapján megállapítottuk, hogy a nemzetközi szakirodalomban felsorolt előnyök nagy többségét itthon is tapasztalták a részvevők és a vállalatok. Ugyan- 
akkor az eredmények számszaki mérése, a pénzbeli hasznok elemzése még igencsak gyerekcipőben jár.

\section{HIVATKOZÁSOK}

Aidoo, H. - Essuman, A. - Aidoo, P. - Yawson, A. O. - Yawson, A. E. (2015): Health of the corporate worker: health risk assessment among staff of a corporate organization in Ghana. Journal of Occupational Medicine and Toxicology, 10:30. DOI 10.1186/s12995-015-0072-7.

AldANA, S. G. (2001): Financial impact of health promotion programs: a comprehensive review of the literature. American Journal of Health Promotion, 15(5), p. 296-320. DOI:10.4278/0890-117115.5.296.

Aldana, S. G. (2018a): How much does an employee wellness program cost? https://www.wellsteps. com/blog/2018/o1/o7/employee-wellness-program-cost/ (letöltve: 2018. február 8.).

Aldana, S. G. (2018b): 5 Workplace Wellness Statistics Every Employer Should Know, https://www. wellsteps.com/blog/2018/o1/o6/workplace-wellness-statistics-wellness-stats/ (letöltve: 2018. február 8.).

Aldana, S. G. (2018c): 7 Reasons Workplace Health Promotion Programs Work, https://www. wellsteps.com/blog/2018/o1/12/workplace-health-promotion-programs/ (letöltve: 2018. február 8.)

AldanA, S. G. (2018d): https://www.wellsteps.com/blog/2018/o7/o4/reasons-to-have-a-wellnessprogram-benefits-of-wellness/ (letöltve: 2018. február 8.).

BAicker, K. - CutLeR, D. - Song, Z. (2010): Workplace wellness programs can generate savings. Health Affairs, 29(2), p. 304-311. DOI: 10.1377/hlthaff.2009.0626.

Baker-Mcclearn, D. - Greasley, K. - Dale, J. - Griffith, F. (2010): Absence management and presenteeism: the pressures on employees to attend work and the impact of attendance on performance. Human Reesource Management Journal, 2o(3), p. 311-328. https://doi.org/10.1111/ j.1748-8583.2009.00118.x.

Baxter, S. - Sanderson, K. - Venn, A. J. - Blizzard, C. L. - Palmer, A. J. (2014): The relationship between return on investment and quality of study methodology in workplace health promotion programs. American Journal of Health Promotion, 28(6), p. 347-363. DOI: 10.4278/ajhp.130731LIT-395.

Boles, M. - Pelletier, B. - Lynch, W. (2004): The relationship between health risks and work productivity. Journal of Occupational and Environmental Medicine, 46(7), p. 737-745. DOI: 10.1097/01.jom.0000131830.45744.97.

BRoокs, C. (2015): Nap Time? Sleeping at Work Boosts Productivity. https://www.businessnewsdaily. com/8165-sleeping-at-work.html (letöltve: 2018. október 8.).

Burton, W. N. - Chen, C. Y. - Conti, D. J. - Schultz, A. B. - Edington, D. W. (2006): The association between health risk change and presenteeism change. Journal of Occupational and Environmental Medicine, 48(3), p. 252-263. DOI:10.1097/01.jom.0ooo201563.18108.af.

DabrónaKI, Á. (2017): A legkomolyabb munkahelyi pszichoszociális kockázat: a stressz. https:// jogaszvilag.hu/cegvilag/a-legkomolyabb-munkahelyi-pszichoszocialis-kockazat-a-stressz/ (letöltve: 2018. október 8.).

DeVol, R. - Bedroussian, A. (2007). An Unhealthy America: The Economic Burden of Chronic Disease Charting a New Course to Save Lives and Increase Productivity and Economic Growth. Milken Institute. Santa Monica, https://www.milkeninstitute.org/publications/view/321 (letöltve: 2018. október 8.). 
Dongen, J. M. - Proper, K. I. - Van Wier, M. F. - Van Der Beek, A. J. - Bongers, P. M. Van Mechelen, W. - VAn Tulder, M. W. (2011): Systematic review on the financial return of worksite health promotion programmes aimed at improving nutrition and/or increasing physical activity. Obesity Reviews, 12(12), p. 1031-1049. DOI: 10.1111/j.1467-789X.2011.00925.x.

EU-OSHA (2018): Prevention of work-related diseases, https:/osha.europa.eu/en/highlights/ prevention-work-related-diseases-eu-osha-launches-new-website-section?pk_ campaign=OSHmail\%2003\%202018. (letöltve: 2018. március 10.).

Eurobarometer (2010): Sport and physical acticity. ec.europa.eu/commfrontoffice/publicopinion/ archives/eb/eb74/eb74_publ_en.pdf (letöltve: 2015. május 12.)

Eurobarometer (2014): Sport and physical acticity. http://ec.europa.eu/public_opinion/archives/ebs/ ebs12_en.pdf (letöltve: 2015. május 12.)

Eurofound (2010): Work-related stress., https://www.eurofound.europa.eu/publications/report/2010/ work-related-stress (letöltve: 2018. október 1.).

Eurofound (2012) Health and Wellbeing at Work: A Report Based on the Fifth European Working Conditions Survey, European Foundation for the Improvement of Living and Working Conditions http://www.eurofound.europa.eu/pubdocs/2013/o2/en/1/EF1302EN.pdf (letöltve: 2016. január 13.).

European Agency For Safety and Health at Work (2010): European Survey of Enterprises on New and Emerging Risks. Managing safety and health at work. https://osha.europa.eu/en/node/6745/ file_view (letöltve: 2015 . január 11.).

European Commission (2017): Safer and Healthier Work for All - Modernisation of the EU Occupational Safety and Health Legislation and Policy, Brussels, 10.1.2017 COM(2017) 12 final.

Eurostat (2018): Gross domestic product at market prices, https://ec.europa.eu/eurostat/tgm/table.do $?$ tab $=$ table\&init $=1 \&$ language $=$ en $\&$ pcode $=$ tecoooo1\&plugin $=1$ (letöltve: 2018 . szeptember 30 .).

Garrow, V. (2016): Preseteeism. A review of current thinking. Institute for Employment Studies, UK: Brigthon.

Goetzel, R. Z. - Pei, X. - Tabrizi, M. - Henke, R. - Kowlessar, N. - Nelson, F.C. - Metz, R. (2012): Ten Modifiable Health Risk Factors Are Linked To More Than One-Fifth Of EmployerEmployee Health Care Spending. Health Affairs, 31(11), p. 2474-2484. 10.1377/hlthaff.2011.0819.

Goetzel, R. Z. - Roemer, E. C. - Liss-Levinson, R. C. - Samoly, D. K. (20o8): Workplace Health Promotion: Policy Recommendations that Encourage Employers to Support Health Improvement Programs for their Workers. http://prevent.org/data/files/initiatives/workplacehealtpromotionpolicyrecommendations.pdf. (letöltve: 2017 . november 1.).

Hayman, S. (2016): The Relationship Between Health Risk and Workplace Productivity in Saudi Arabia. Doctoral Dissertation, Walden University, https://scholarworks.waldenu.edu/ dissertations/3034/ (letöltve: 2018. október 8.).

Health Management (2018): A brief history of occupational health, https://www.healthmanagement. co.uk/sites/default/files/paragraph/image/Health-Management_brief-history-occupationalhealth.pdf (letöltve: 2018. november 4.).

Henke, R. M. - Goetzel, R. Z. - Mchugh, J. - IsaAc, F. (2011): Recent experience in health promotion at Johnson \& Johnson: lower health spending, strong return on investment. Health Affair, 30(3), p. 490-499. DOI: 10.1377/hlthaff.2010.0806.

International Organization for Standardization (2018): ISO 31000 - Risk management, https://www. iso.org/iso-310oo-risk-management.html (letöltve: 2018. március 11.).

Kirkham, H. - Bobby, L. C. - Bolas, C. A. - Lewis, G. H. - Jackson, A. S. - Fisher, D. - Duncan, I. (2015): Which Modifiable Health Risks Are Associated with Changes in Productivity Costs? Population Health Management, 18(1) https://doi.org/10.1089/pop.2014.0033. 
KPMG Econtech (2011): Economic Modelling of the Cost of Presenteeism in Australia: 2011 Update, Report for MediBank Private, August 2011.

KSH (2018a): A bruttó hazai termék (GDP) értéke forintban, euróban, dollárban, vásárlóerő-paritáson (1995-), http://www.ksh.hu/docs/hun/xstadat/xstadat_eves/i_qpto15.html (letöltve: 2018. szeptember 30.).

KSH (2018b): Munkaidőmérleg 2016, Statisztikai Tükör, 2018. július 2., http://www.ksh.hu/docs/ hun/xftp/stattukor/munkaidomerleg16.pdf (letöltve: 2018. november 7.).

LECHNER, M. (2009): Long-run labour market and health effects of individual sports activities. Journal of Health Economics, 28(4), p. 839-854.

Lenneman, J. - Schwartz, S. - Giuseffi, D. L. - Wang, C. (2011): Productivity and health: an application of three perspectives to measuring productivity. Journal of Occupational and Environmental Medicine, 53(1), p. 55-61, DOI: 10.1097/JOM.obo13e3182029110.

Merrill, R. M. - Aldana, S. G. - Pope, J. E. - Anderson, D. R. - Coberley, C. R. - Grossmeier, J. J. - Whitmer, R. W. (2013): Self-rated job performance and absenteeism according to employee engagement, health behaviors, and physical health. Journal of Occupational and Environmental Medicine, 55(1), p. 10-18. DOI: 10.1097/JOM.obo13e31827b73af.

MGYOSZ (2010): Az egészséges munkavállalókért és a biztonságos munkahelyekért. www. euromenedzser.hu/hu/kiadvanyaink (letöltve: 2013. november 1.).

Mills, P. R. (2005): The development of a new corporate specific health risk measurement instrument, and its use in investigating the relationship between health and well-being and employee productivity. Environmental Health, 4(1), 1. DOI: 10.1186/1476-069X-4-1.

O'Donnell, M. P. (2000): Health and productivity management: the concept, impact, and opportunity. Commentary to Goetzel and Ozminkowski. American Journal of Health Promotion, 200o, 14, p. 215-217.

OECD (2017): Obesity Update. https://www.oecd.org/els/health-systems/Obesity-Update-2017.pdf (letöltve: 2018. október 8.).

Oliveira, K. - Méxas, M. - Meiriño, M. - Drumond, G. (2018): Critical success factors associated with the implementation of enterprise risk management. Journal Of Risk Research, p. 1-16, DOI: 10.1080/13669877.2018.1437061.

Országos Munkahelyi Stressz Felmérés (2013): Eredmények, http://www.munkahelyistresszinfo. hu/a-munkahelyi-stressz-merese/munkahelyi-stressz-felmeres-eredmenyek/ (letöltve: 2018. október 8.).

Pelletier, B. - Boles, M. - Lynch, W. (2004): Change in health risks and work productivity over time. Journal of Occupational and Environmental Medicine, 46(7), p. 746-754.

Pénzcentrum (2018): Súlyos népbetegség ütötte fel a fejét: veszélyesebb, mint a dohányzás. https:// www.penzcentrum.hu/biztositas/sulyos-nepbetegseg-utotte-fel-a-fejet-veszelyesebb-mint-adohanyzas.1070458.html (letöltve: 2018. október 8.).

Polgár, B. (2018): A kövérek országa vagyunk? https://www.veol.hu/eletstilus/helyi-eletstilus/ hazankban-felmeres-szerint-harom-felnottbol-ketto-tulsulyos-vagy-elhizott-2221673/ (letöltve: 2018. október 8.).

Rand Europe (2016): Why sleep matters - the economic costs of insufficient sleep. A cross-country comparative analysis, https://www.rand.org/pubs/research_reports/RR1791.html (letöltve: 2018. október 8.).

Randstad Workmonitor (2014): Healthy employees perform better. https://www.randstad.com/.../ randstad-workmonitor (letöltve: 2015. január 11.).

Ser Xner, S. - Gold, D. B. - Bultman, K. K. (2001): The impact of behavioral health risks on worker absenteeism. Journal of Occupational and Environmental Medicine, 43(4), p. 347-354. 
Sleep Council, The (2013): The Great British Bedtime Report. https://www.sleepcouncil.org.uk/wpcontent/.../The-Great-British-Bedtime-Report.pdf (letöltve: 2018. október 8.)

SzABó, A. (2018): A Magyar GDP hatszorosába kerül évente Európában a munkahelyi stressz. http:// www.munkahelyistresszinfo.hu/stressz-a-munkahelyen/a-stressz-hatasai/a-magyar-gdphatszorosaba-kerul-evente-europaban-a-munkahelyi-stressz.php (letöltve: 2018. október 8.).

Szinapszis (2013): Már a munkahelyen is számít az egészség. http://www.webbeteg.hu/cikkek/ egeszseges/14720/mar-a-munkahelyen-is-szamit-az-egeszseg (letöltve: 2013. augusztus 10.).

Tasmania (2012): Your Simple Guide to Workplace Health and Wellbeing. http://worksafe.tas.gov. au/__data/assets/pdf_file/ooo3/252390/Your_Simple_Guide_to_Workplace_Health_and_ Wellbeing.pdf (letöltve: 2015. január 11.).

Vaughan-Jones, H. - Barham, L. (2009): Healthy Work Challenges and Opportunities to 2030. London: Press Office Bupa.

Virgin Pulse (2017): Clocking in and checking out, https://connect.virginpulse.com/files/ presenteeism-in-the-workplace.pdf (letöltve: 2018. november 7.).

Vöő, Gy. (2018): Csúcsot döntött az igazolatlan munkahelyi távollét, https://www.vg.hu/gazdasag/ gazdasagi-hirek/csucsot-dontott-az-igazolatlan-munkahelyi-tavollet-2-985216/ (letöltve: 2018. november 1.).

WHAA (2016): ROI White Paper. Workplace Health Association of Australia.

WHO (2010): Healthy Workplace Framework and Model, www.who.int/occupational_health/ healthy_workplace_framework.pdf (letöltve: 2013. július 1.).

Willis Towers Watson (2016): Employee Health and BusinessSuccess.https://www.willistowerswatson. com/en/insights/2016/o3/stayingatwork-report-employee-health-and-business-success (letöltve: 2018. október 8.).

Witters, D. - Agrawal, S. (2015): Well-Being Enhances Benefits of Employee Engagement. Business Journal, October 27, http://news.gallup.com/businessjournal/186386/enhances-benefitsemployee-engagement.aspx (letöltve: 2018. február 28.).

Xerox (2016): Working Well: A Global Survey of Workforce Wellbeing Strategies 2016 - Survey report, 7th ed., http://www.globalhealthyworkplace.org/casestudies/2016_Global_Wellbeing_ Survey_Executive-Summary.pdf (letöltve: 2018. február 10.). 